\title{
The influence of political connection on corporate social responsibility-_evidence from Listed private companies in China
}

\author{
Haifeng Huang ${ }^{1 *}$ and Zhenrui Zhao ${ }^{2}$
}

\begin{abstract}
In recent years, Chinese private companies have improved a lot in corporate social responsibility (CSR) performance, especially in the philanthropic area. However, private companies' awareness and performance of social responsibility still have a big disparity with SOEs. And private companies' policy of social responsibility is subjective and preferential. To explain this contradiction, this paper tries to introduce political connection and, based on stakeholder salience theory, to test how political connection changes managers' perception of stakeholders' relative importance and cause changes in stakeholders' satisfaction level of social responsibility requirement. The result shows that (1) political connection has positive influence on private companies' CSR; (2) companies with political connection are significantly better than the ones without political connection in society-oriented and customers-oriented responsibility; (3) two kinds of companies have no significant difference in investors-oriented responsibility; (4) as for government-oriented and employee-oriented responsibility, companies with political connection are worse than ones without political connection. These findings are significant for China's future construction of competition system and private companies' choice of stakeholders and future investment.
\end{abstract}

Keywords: Political connection, Corporate social responsibility, Stakeholder salience theory

\section{Introduction}

Chinese scholars' discussion on Corporate Social Responsibility (CSR) developed rapidly from the 1990s. The Chinese government gradually implemented a series of laws, regulations and guidelines. The newly-amended Company Law in 2005 first defined CSR on a perspective of law and pointed out clearly that a company should improve the awareness of social responsibility when pursing profitability. China's SASAC issued the Guidelines for Central Enterprises to Fulfill Social Responsibilities in 2008, which is the first normative document of CSR issued by the ministry. The same year the Shanghai Stock Exchange issued the Announcement about Strengthening Listed Companies' Performance of Social Responsibility, which encourages listed companies to publish their concrete performance towards stakeholders' social responsibility and appeals to companies

\footnotetext{
*Correspondence: huanghf@phbs.pku.edu.cn

${ }^{1}$ Peking University HSBC Business School, Room 736, University Town,

Nanshan District, Shenzhen, Guangdong Province 518055, China

Full list of author information is available at the end of the article
}

to issue corporate social responsibility reports. Government's efforts encouraged companies' positive response. According to the Research Report on Corporate Social Responsibility of China (Huang et al. 2014) issued by the Chinese Academy of Social Sciences, the CAGR of Chinese CSR development index reached $16.80 \%$ since 2009 .

An important component of China's economy, private companies have become an important power that is spurring China's economic development expanding employment, and improving people's well-being. In recent years, a private company's performance of social responsibility is heading in the right direction. CSR's content is richer and includes charitable donation, fund raising, environment protection, and etc. (Xiao \& Xu 2011). Private companies are the backbone of donation. According to Annual Report on China's Philanthropy Development (Yang 2009), the proportion of private companies' total donation is more than half of all companies' donation. What is the motivation that is pushing private companies to increase their investment in CSR? Compared to state-owned companies and foreign-funded companies, private 
companies have been treated unjustly in terms of laws and regulations for a long time. With a limited ability to obtain resources, private companies' survival and development space are relatively small. During China's economic transition, marketization has been low, and government's intervention in the economy has been strong. Key resources which are vital to companies' development are controlled by government. Under these disadvantages, private companies would, therefore, prefer to build and maintain connections with government to advance their development. In order to maintain political connection, based on the reciprocity theory, companies should meet government's needs. Politically connected companies will increase its investment in CSR as the government focuses on social responsibility.

However, private companies' awareness and performance of social responsibility still have a big disparity with other types of companies, especially SOEs. Private companies' CSR lacks systematization and purposefulness, and does not possess a fixed management team that handles social responsibility (Gu 2015). All these make private companies' policy of social responsibility subjective and preferential. For example, when private companies get actively involved in philanthropy, they also become the subject of labor trouble, security incidents, and quality issues. According to the Report on Chinese Social Opinion and Crisis Management (Lian 2014), more than $40 \%$ of financial and economic events are about private companies. Faced with the contradiction of private companies' performance in CSR, this paper wants to provide an explanation from the stakeholder theory. As business development's process involves many stakeholders, which are vital to companies' survival and development, companies should bear relative obligations and responsibilities (Clarkson 1995). If companies fail to deal with the different stakeholders' relationships, companies' sustainable development will be affected. However, due to enterprises' limited resources, firms cannot satisfy all stakeholders' needs. Donaldson \& Perston (1995) consider that not all stakeholders' requirements are reasonable. Therefore, firms should balance among diverse stakeholders and satisfy stakeholders' social responsibility requirement selectively based on stakeholders' importance. Mitchell et al. (1997) defined stakeholders' salience theory based on their characteristics, legitimacy, power, and urgency, which provide a theoretical basis for this paper. Stakeholders' salience is dynamic. And, stakeholders can change managers' perception of salience through the use of political power and the foundation of alliances. For private companies, the introduction of political connection may change managers' judgement toward stakeholders' relative importance, and, then, change the different stakeholders' satisfaction level of social responsibility.

In summary, this paper attempts to answer the following questions: (1) Under the background of economic transition, what is the impact of political connection on private companies' performance of social responsibility? (2) Whether the introduction of political connection changes managers' perception of stakeholders' relative importance and, then, cause changes in stakeholders' satisfaction level of social responsibility requirement.

\section{Literature review \\ Definition and measurement of Corporate Social Responsibility}

The researcher, who first proposed the concept of CSR, is Oliver Sheldon. He defined CSR as a businessman who satisfies the internal and external requirements. Before the 1960s, scholars used Social Responsibility of the Businessman as the CSR undertaker, not the company. Bowen, who is the Father of Corporate Social Responsibility and who first systematically defined CSR, also pointed out that the businessman has the responsibility to develop policies in accordance with established social goals and values, and a businessman's voluntary performance of social responsibility is the effective method to improve the economy and achieve economic goals.

Until the 1970s, scholars tried to define CSR more precisely and change the CSR undertaker from the businessman to a company. To further define the content and object of CSR, scholars formed two definition methods.

(1)Levels of Analysis. Carroll's interpretation is a classic in a related field. He divided social responsibility into economic responsibility, legal responsibility, ethical responsibility and philanthropic responsibility. These four categories of CSR might be depicted as a pyramid from bottom to top. Economic responsibility, which is the foundation of the other three responsibilities means that companies have the responsibility to manufacture, make profit, and satisfy customers' needs. Legal responsibility means the company should comply with the laws and regulations promulgated by federal, state and local governments as ground rules. Ethical responsibility embraces those activities and practices that are expected or prohibited by societal members and embodies those standards, norms, or expectations that reflect a concern for what consumers, employees, shareholders, and the community regard as fair, just, or in keeping with the interests or protection of stakeholders' moral rights. Philanthropic responsibility encompasses those corporate actions that are in response to society's expectation that businesses be good corporate citizens (Carroll 1979 \& 1991).

(2) Stakeholder Perspective. This method is based on the stakeholder theory that gained popularity in the second half of the twenty-century. The combination with stakeholder theory helps CSR research provide a 
more clear definition and precise measurement method. It also provides a theoretical foundation. Stakeholder theory is called by scholars the most closely related theoretical framework within CSR. The method, levels of analysis, verifies the content of CSR; however, it does not solve the problem of whose responsibility CSR should be. The word "Social" in CSR has not been clearly defined for a long time, giving a simple understanding among people. The introduction of CSR clarifies the meaning of "Social" (Carroll 1991).

The following is a discussion of stakeholderoriented responsibility. In order to define related stakeholders of CSR, scholars have done a lot of research. Most scholars agree that investors, employees, and customers compose stakeholders. Besides the above three, Freeman used a stakeholder map to include competitors, unions, and suppliers (Edward 1994). Based on the balance of stakeholders' urgency, power and legitimacy, government was incorporated by Agle \& Sonnenfeld (1999). According to Carroll's philanthropic responsibility, Li incorporated society (Li 2006). With the extension of sustainable development, the environment and community relations were incorporated (Waddock \& Graves 2009). In addition, women and minority groups, product or service quality are sometimes mentioned (Greenley \& Foxall 1998).

Based on data availability and according to a Shanghai Stock Exchange's document, the Announcement about Strengthening Listed Companies' Performance of Social Responsibility, which mentioned shareholder, employee, customer, creditor, community, and government, this paper selects society, investors, customers, employees and government as the five core stakeholders to discuss political connection's influence on different stakeholder's required responsibility. This paper defines CSR as part of companies undertakings related to economic, legal, ethical, and philanthropic responsibilities to core stakeholders, and positive impact on stakeholders as described in Table 1 below.

There are three commonly used CSR measuring methods. (1) Content Analysis: This method mainly determines score or numerical value of various aspects of social responsibility through collecting and analyzing companies' published reports, especially the annual reports. (2) Reputation Index: This method calls industry veterans to evaluate companies' CSR policies and then sort the sample companies. (3) Grade of Professional Institutes: This method refers to the CSR database created by professional institutes. The KLD index given by American KLD Company is the most accepted and widely used. In China, the authoritative and widely used database is given by Rankings CSR Ratings (RKS).

Chinese scholars primarily use grades from professional institutes. However, when combining stakeholders with CSR, Chinese scholars mainly utilize the questionnaire method and the content analysis method based on financial reports for the lack of professional database from the perspective of stakeholders such as the KLD database. For questionnaires, the samples are always small and the cost is high. So content analysis is mainly used. Later, I summarize the research results that use financial indicators to measure CSR.

\section{Research based on government's formulas}

There are two basic formulas. One is the social contribution rate given by China's Ministry of Finance in 1995. The other is the social contribution value per share given by the Shanghai Stock Exchange in 2008. Social contribution rate means that the company creates a contribution to society with certain assets. The more contribution the company creates with the same amount of assets, the higher the economic and social benefits of the company. The formula is shown as follows:

\section{Social Contribution Rate $=$ Amount of Social Contribution / Average Total Asset}

The total amount of social contribution includes employees' wages (bonuses, allowances, etc.), labor retirement investment, and other social welfare expenditures, net interest payments, value added tax payable, sales tax and extra charges, other taxes, and net profit.

Social contribution value per share means the sum of profits for shareholders and for other stakeholders. The

Table 1 Companies' responsibility to stakeholders

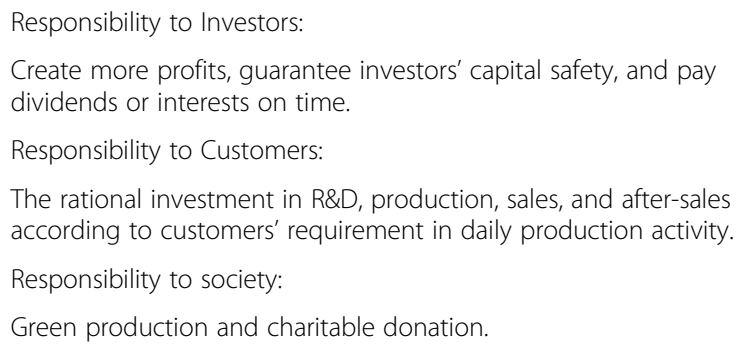

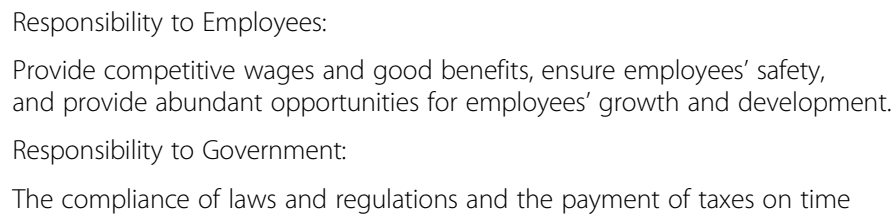


higher the index, the better CSR performance a company has. The formula is shown as follows:
Social Contribution Value per Share $=$ Earnings per Share + / Shareholder Equity
$($ Total Tax + Employee Cost + Interest Expenditure + Public Welfare Expenditure-Social Cost
Many scholars modify the above formulas to calculate CSR and stakeholder-oriented responsibility. For the social contribution rate formula, (Cheng 1995) used sales income instead of total average assets to make it more suitable for companies' social achievements. Chen \& Ma (2005) used the data based on cash system of accounting instead of the numerator based on accrual basis to make the formula attract more users' attention, which is shown in Table 2.

According to previous researches, Zhou, Wang and Liu calculated stakeholder-oriented social responsibility based on Carroll's division of CSR and quantifiable and accessible data as seen in Table 3 (Zhou et al. 2008).

Zhu divided CSR's objectives into internal and external stakeholders, and measure the relevant investment with absolute and relative method, shown in Table 4 below.

When calculating the total value of CSR, besides the basic two formulas above, some researches make some improvement, which is shown in Table 5.

The advantage of this method is calculations based on government and relevant organizations' formula, which has a certain authority. The disadvantage is that it does not consider stakeholders' discrepancy of significance and influence on a company.

\section{Weights endowed method}

This method calculates total CSR based on the weight of different stakeholders. However, the complexity and data availability hinder the use of this method.

Shen calculated the weight of shareholders, creditors, employees, consumers, suppliers, and government based

Table 2 Calculation of stakeholder-oriented responsibility

\begin{tabular}{ll}
\hline Stakeholders & Contribution Rate \\
\hline Contribution to Government & $\begin{array}{l}\text { (Tax Payments-Tax Returns)/Cash } \\
\text { Inflow From Operating Activities }\end{array}$ \\
Contribution to Employee & $\begin{array}{l}\text { Cash Paid to Employee and for } \\
\text { Employee / Prime Operating Revenue }\end{array}$ \\
Contribution to Investor & $\begin{array}{l}\text { Dividend and Interest Paid in Cash/ } \\
\text { Prime Operating Revenue }\end{array}$ \\
Contribution to Society & $\begin{array}{l}\text { (Environment Expenditure + Donation + } \\
\text { Sponsorship Fee)/ Prime Operating } \\
\text { Revenue }\end{array}$ \\
\hline
\end{tabular}

on comprehensive, quantitative, comparable, and operational principles (Shen \& Shen 2003, 2004), shown in Table 6 below. This method guided subsequent researchers (Qiu \& Xu 2005).

Gao and Peng calculated stakeholders' weight from the dynamic life-cycle perspective. According to companies' period of founding, growing, maturing, and declining, companies pay different attention on the same stakeholders (Gao \& Zhou 2011), shown in Table 7.

The above research results show that when measuring stakeholder-oriented responsibility, the chosen indicators do not have an impact. To measure a company's contribution to society, scholars use donation expenses in nonbusiness expenditure part. To measure company's contribution to employee, scholars use the wage and welfare rate and wage growth rate. To calculate the governmentoriented responsibility, scholars use tax ratio. For customer-oriented responsibility, operating cost ratio and sales growth rate are used. For investor-oriented responsibility, net asset value per share, earnings per share, and asset-liability ratio, are used. The specific calculation method of this paper will be introduced in Chapter 4 .

\section{Definition and measurement of political connection}

Researches on political connection began in the 1970s. Krueger pointed out that entrepreneurs could build connection with government officials to bring economic benefits (Krueger 1974). The definition of political connection has not reached an agreement. In a narrow sense, political connection is when corporate executives or major shareholders have government working experience, or have a

Table 3 Calculation of stakeholder-oriented responsibility

\begin{tabular}{ll}
\hline Stakeholders & Contribution Rate \\
\hline Contribution to Country & $\begin{array}{l}\text { (Tax Payments-Tax Returns)/ } \\
\text { Prime Operating Revenue }\end{array}$ \\
Contribution to Employee & $\begin{array}{l}\text { Cash Paid to Employee and for Employee/ } \\
\text { Prime Operating Revenue }\end{array}$ \\
Contribution to Investor & $\begin{array}{l}\text { Dividend and Interest Paid in Cash/ } \\
\text { Prime Operating Revenue } \\
\text { Contribution to Society } \\
\text { Public Welfare Paid in Cash/ } \\
\text { Prime Operating Revenue }\end{array}$ \\
\hline
\end{tabular}


Table 4 Calculation of stakeholder-oriented responsibility

\begin{tabular}{cl}
\hline Absolute Value & Indicator \\
\hline Inner Stakeholders & Staff Training Expenditure \\
& Staff Social Security Expenditure \\
External Stakeholders & Donation \\
& Pollution Control Expenditure \\
Relative Value & Indicator \\
Inner Stakeholders & Staff Training Expenditure/Revenue \\
& Staff Social Security Expenditure/Revenue \\
External Stakeholders & Donation/Revenue \\
& Pollution Control Expenditure/Revenue \\
\hline
\end{tabular}

close connection with officials (Faccio 2006). In a broad sense, political connection is when a company has a close connection with government actively or passively to pursue self-development. Recessive political connection based on entrepreneurs' social relationships is also included in political connection (Sun 2012). Considering the difficulty and inscrutability to measure recessive political connection, scholars mainly focus on the narrow sense. The following summarizes several measurement method of political connection depending on the background of each country.

(1)Dummy Variable Method. Foreign scholars think if the controlling shareholders, directors, or executives are comprised of senators and ministers or have a close connection with politicians, the company is seen as having political connection, which equals to 1 . If not, political connection equals to 0 (Faccio 2006; Francis et al. 2009). Chinese scholars think if the executives (chairman and general manager; chairman or general manager; the board of directors and general manager; directors, supervisors, and

Table 5 Formula of CSR

\begin{tabular}{cl}
\hline Scholar & Formula \\
\hline Gao \& Zhou (2008) & (Dividend Paid in Cash + Interest Paid in Cash + \\
& Cash Paid to Employee and for Employee + \\
& Cash Paid to Customer + Cash Paid for Goods \\
& Purchased and Labor Services Received + \\
& Actual Tax Paid)/ Prime Operating Revenue \\
Zhang \& Liang (2012) & (Dividend Paid in Cash + Interest Paid in Cash + \\
& Cash Paid to Employee and for Employee + \\
& Cash Paid to Customer + Cash Paid for Goods \\
& Purchased and Labor Services Received + \\
& Actual Tax Paid + Donation)/ Prime Operating \\
& Revenue \\
& (Tax Payments-Tax Returns + Cash Paid to \\
& Employee and for Employee + Dividend Paid \\
& in Cash + Interest Paid in Cash + Notes \\
& Payable + Accounts Payable)/ Prime \\
Cao \& Yu [2013] & Operating Revenue \\
\hline
\end{tabular}

Table 6 Calculation of CSR and stakeholder-oriented responsibility

\begin{tabular}{|c|c|}
\hline Item & Formula \\
\hline \multirow[t]{2}{*}{ Stockholder } & Earnings per Share \\
\hline & Net Asset Value per Share \\
\hline \multirow[t]{2}{*}{ Creditor } & Interest Coverage Ratio \\
\hline & Equity to Asset Ratio \\
\hline \multirow[t]{2}{*}{ Customer } & COGSTS \\
\hline & Sales Growth Rate in 3 Years \\
\hline \multirow[t]{2}{*}{ Supplier } & Accounts Receivable Turnover \\
\hline & Ratio of Cash and Accounts Payable \\
\hline \multirow[t]{2}{*}{ Employee } & Wages and Welfare Ratio = Wages and Welfare $/$ Net Profit \\
\hline & Wages and Welfare Growth Rate \\
\hline \multirow[t]{2}{*}{ Government } & Tax Ratio \\
\hline & Tax Growth Rate in 3 Years \\
\hline \multirow[t]{3}{*}{ Weight } & $\begin{array}{l}\text { Stockholder's Weight }=\text { Stock Equity/ Total Asset + } \\
(\text { Subject Equity/ Total Asset) } *(\text { Dividend /(Stockholder + } \\
\text { Creditor + Customer + Supplier + Employee + Government)) }\end{array}$ \\
\hline & $\begin{array}{l}\text { Creditor's Weight }=\text { Loans } / \text { Total Asset }+(\text { Subject Equity/ } \\
\text { Total Asset })^{*} \text { (Interests } /(\text { Stockholder }+ \text { Creditor }+ \\
\text { Customer + Supplier + Employee + Government }))\end{array}$ \\
\hline & $\begin{array}{l}\text { Other Stakeholders' Weight }=(\text { Subject Equity/ Total Asset }) \\
* \text { (Other Related Stakeholder's Expenditure /(Stockholder } \\
+\underset{6}{+ \text { Creditor }+ \text { Customer + Supplier + Employee + Government }))}\end{array}$ \\
\hline CSR & $\begin{array}{l}C S R=\sum_{n=1}\left(C S R_{i} * W_{i}\right) \\
\left(C S R_{i} \text { is the indicator of stakeholder-oriented responsibility. }\right. \\
W_{i} \text { is stakeholder's weight) }\end{array}$ \\
\hline
\end{tabular}

executives) are or have been government officials, NPC delegates, CPPCC delegates, Party Congress delegates, et al., the company is seen as having political connection which equals to 1 . If not, political connection equals to 0 (Li 2010; Wang \& Wu 2008; Yu \& Pan 2008).

(2)Political Level Valuation Method. To better measure the difference of political connection levels, some scholars give different levels numerical values, respectively. Political connection equals to 5 with national connection; equals to 4 with provincial connection; equals to 3 with municipal connection; equals to 2 with county-level connection; equals to 1 with township-level connection; and equals to 0 with no connection (Du et al. 2009; Wu 2014).

(3) Proportion Method. This method includes politically connected executives of total executives, nationalconnected executives of total executives, and localconnected executives of total executives (Boubakri 2008; Deng \& Zeng 2009; Qiu \& Xu 2015).

Besides the above three methods, political donation expenditure method (Goldman 2006), Suharto dependent index (Fisman 2001), geographical factors analysis method (Faccio \& Parsley 2009) are additional methods used by 
Table 7 Calculation of CSR and stakeholder-oriented responsibility

\begin{tabular}{|c|c|}
\hline Item & Formula \\
\hline Stockholder & $\begin{array}{l}\text { Dividend Paid in Cash/ Prime Operating } \\
\text { Revenue }\end{array}$ \\
\hline Creditor & Interest Expense/ Prime Operating Revenue \\
\hline Employee & $\begin{array}{l}\text { Cash Paid to Employee and for Employee / } \\
\text { Prime Operating Revenue }\end{array}$ \\
\hline Customer & R \& D/ Prime Operating Revenue \\
\hline Supplier & $\begin{array}{l}\text { Cash Paid for Goods Purchased and Labor } \\
\text { Services Received/ Prime Operating Revenue }\end{array}$ \\
\hline Government & $\begin{array}{l}\text { (Tax Payments_-Tax Returns)/ Prime } \\
\text { Operating Revenue }\end{array}$ \\
\hline Community & $\begin{array}{l}\text { (Donation + Sponsorship Fee)/ Prime } \\
\text { Operating Revenue }\end{array}$ \\
\hline $\begin{array}{l}\text { Negative Contribution } \\
\text { Rate }\end{array}$ & $\begin{array}{l}\text { - (Amercent Outlay + Compensation } \\
\text { Expenses + Overdue Fine)/ Prime } \\
\text { Operating Revenue }\end{array}$ \\
\hline CSR Performance & $\begin{array}{l}C S R=\sum_{n=1}\left(C S R_{i} * W_{i}\right) \\
\left(W_{i} \text { is the recognition level of stakeholders }\right. \\
\text { in different life-cycles. })\end{array}$ \\
\hline
\end{tabular}

scholars. Political donation expenditure is the lobbying spending or political donation. Geographical factors mean that the hometown of Congress members is the same as corporate headquarters. However, these three methods' applicable range is limited.

Considering China's actual condition and the availability of data, this paper uses the dummy variable method and considers whether chairman of the board or general manager is or had been a government official, NPC delegates, CPPCC delegates, Party Congress delegates, then political connection equals to 1 . If not, political connection equals to 0 . In the robust test part, this paper uses political level valuation method.

\section{Motivation of Corporate Social Responsibility}

Motivations of companies' performance of CSR are complicated. To sum up, the motivations can be divided into internal motivation and external pressure.

(1)Internal Motivation. Swanson considers internal motivation includes positive-duty and utilitarian. Positive-duty means that the company is willing to perform social responsibility whether there exists external factor or not. Utilitarian means that the performance of CSR is to pursue self-performance goals (Swanson 1995). Scholars after Swanson are based on his results. Even though the name is different, the connotation is similar. For example, Li et al. (2010) distinguished between value-driven factor and performance-driven factor; (Sánchez 2006) pointed out altruistic motive and profit maximization motive; and Aguilera et al. (2007) used moral motive and instrumental motive. Agent theory is applied to motivation research and forms over-investment hypothesis (Barnea \& Rubin 2010; Goel \& Thakor 2008; Gompers 2003). Executives may over invest in social responsibility in order to build their own social reputation when they are in charge of companies' operation.

(2)External Pressure. Negative-duty is an explanation of external pressure given by Swanson, which means CSR is companies' passive response to external stakeholders (Swanson 1995). Stakeholder-driven theory (Li et al. (2010), political and institutional power motive (Sánchez 2000), relational motive (Aguilera 2007) are also mentioned by scholars.

The classification of internal motivation and external pressure is simple; however, there may exist some overlap, which is hard to distinguish. Godfrey (2005) used company strategic motives in CSR motivation analysis and combined utilitarianism with external pressure.

China's CSR motivation researchers mainly learn from foreign research results and use external and internal methods. Sun and Zhong divided the motivation factors into economic motivation (including value-added driven and agent problem) and non-economic motivation (including politically driven and morally driven). SOEs' CSR is mainly driven by agent problems, and private companies' CSR is mainly driven by value-added and political protection ( $\mathrm{Su}$ 2011). Zhang (2013) proposed the structure of "Competition-Commitment-Compliance" based on Swanson's theory. Competition means that CSR performance is to satisfy companies' target of self-profits and overcoming the competition. Commitment is companies' or executives' contribution to society based on their philosophy. Compliance means companies execute social responsibility according to external pressure (Fig. 1).

This paper treats political connection's influence as the combination between internal utilitarian and external political pressure, which will be discussed in the next part in detail.

\section{Political connection and Corporate Social Responsibility Internal utilitarian}

Based on resource effect of political connection, it is an important social capital. Companies can obtain required key resources through political connection, which is in accordance with utilitarianism.

Political connection's resource effect researches are comprehensive and in-depth from basic theory to empirical analysis. For fund-raising, political connection can help connected companies to obtain bank loans more 


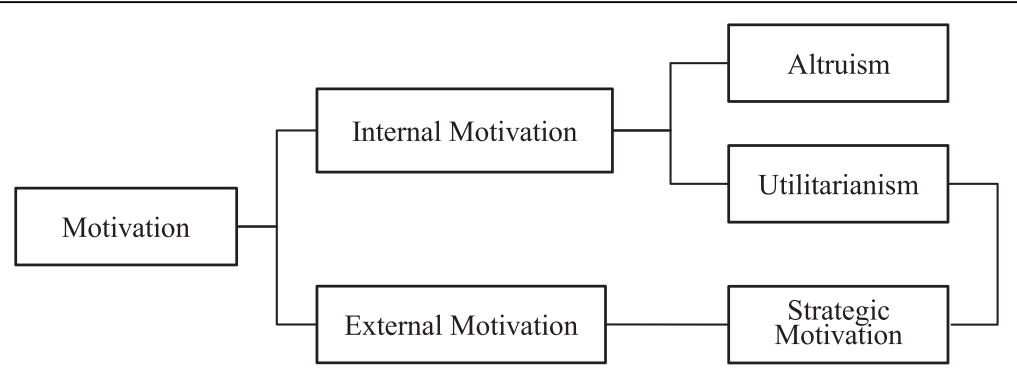

Fig. 1 CSR motivation

easily, especially long-term loans (Mian \& Khwaja 2005). Connected companies can improve the ability of capital acquisition through a high corporate quality signal ( $\mathrm{Hu} 2006)$. For government's support and protection, political connection allows for $\mathrm{s}$ more tax preference for connected companies, and they would remove barriers more easily and then improve competitiveness and values (Faccio 2006; Wang \& Wu 2008; Luo \& Huang 2008). When facing difficulty, politically connected companies may obtain more government assistance. Political connection can also be the alternative mechanism for imperfections in the economic and legal systems to protect companies' property from government damage (Sun 2005; Yu \& Pan 2008).

\section{External political pressure}

According to social exchange theory, establishing, maintaining, and improving political connection require companies' investment to meet government's need. With government's increased attention on CSR, companies are pressed to perform social responsibility.

Aronson, Wilson and Akert (2005) considered that political connection is a recessive contract. Based on reciprocity and fairness principle of social exchange, companies should help government solve problems when they receive help from government. In the CSR field, government tries to maintain society's stability and development, and officials strive to increase their achievements. Therefore, they expect companies to bear relevant social responsibility through recessive contracts of political connection (Li 2010). To maintain and improve this recessive contract, a company may step forward to fill government needs and bear social responsibilities, which originally belonged to government (Zhang \& Liang 2012). Thus, political connection has positive influence on companies' performance on social responsibility. In fact, the higher the political connection level, the better companies take responsibility (Yi \& Xu 2014).

In terms of the relationship between political connection with donation, researches show that politically connected companies are more prone to accept government apportions and have a higher propensity to donate. Jia and Zhang analyzed companies' motivation to donate based on sample contributions after the 2008 Wenchuan earthquake. They proposed that maintaining and improving relationship with government is a main reason that causes companies to donate assets (Jia \& Zhang 2010). Scholars also find that Chinese companies can build political connection through charity activities, and then get more loans, investing opportunities, etc. (Su \& He 2009).

Political connection's influence on enterprises, however, is not always positive. Close connection with government will sometimes spur a decrease in stock value and sales growth when the government is faced with negative rumors such as a leader's health deterioration or death (Faccio \& Parsley 2007; Fisman \& Wang 2015). Some researchers found that compared with connected companies, non-connected companies demonstrate a better performance on sales returns and profit growth (Fan et al. 2007; Wang \& Wu 2008). In the social responsibility field, some researchers pointed out that political connection may be a cause for companies' immoral activities because government is less stringent on regulation. Fan et al. (2007) found that Chinese politically connected companies will use Guanxi to bypass labor protection laws and regulations to decrease cost and increase profit. Dong and Luo found that party organization in private companies does not improve employees' wages from the perspective of the relationship between party and companies (Dong et al. 2014). Fisman's and Wang's research shows that the death rate of political connected companies is 2-3 times higher than non-connected companies, which is attributed to connected companies use of Guanxi to bypass government's safety checks and regulations and decreasing investments in employees' safe work environment and environmental protection (Fisman \& Wang 2015).

\section{Stakeholder saliency theory}

Currently, researches on stakeholder theory can be divided into description analysis, instrumental analysis, and normative analysis. Description analysis mainly solves the question of who are companies' stakeholders. In this paper, we choose investors, customers, employees, government, and society as the stakeholders. Instrumental analysis discusses stakeholders' influence on business strategy and the stakeholder management strategy based on the analysis of the relationship between 
stakeholder management and traditional companies' targets. It also includes the research of stakeholders' analysis, which is the core of this paper. Normative analysis attempts to prove the rationality of stakeholder theory from an abstract perspective.

Instrumental researches consider that companies cannot satisfy all stakeholders' requirement and companies should prioritize stakeholders based on their relative importance and then meet their needs tactically. The concept of salience is formed as a result of managerial evaluations of stakeholders' priority levels when they deal with conflicting stakeholders' needs. In other words, salience is the ranking of stakeholders from a manager's perception (Mitchell et al. 1997). Salience is a comprehensive judgment of stakeholders' value and distinguishes important and unimportant stakeholders. The stakeholder salience research is based on Mitchell, Agle and Wood's achievement, which uses stakeholders' legitimacy, urgency and power to determine salience. Power means the ability and method of a stakeholder to affect company's decision. Legitimacy means a stakeholder's obligations given by laws, regulations and social duty. Urgency means a stakeholder's requirement or demand can be taken into account or solved by managers. Figure 2 shows the relationship among stakeholders' three characteristics.

Mitchell pointed out that if a stakeholder has at least one characteristic of the three, it can get the companies' attention. Scholars apply this theory into CSR, discuss the importance of different stakeholders for CSR, and then devise CSR strategy. Agle \& Sonnenfeld (1999) found that CSR is directly related to stakeholders. In addition, increasing consumer's and government's importance will increase the performance level of social responsibilit. Maignan and Ralston (Maignan \& Ralston 2002) found that consumers and community are the most important participants that push companies to partake in environmental social responsibility. For SMEs, the most important stakeholders are government (Williamson et al. 2006), competitors (Jenkins 2006) and consumers (Perrini et al. 2007).
In conclusion, companies can judge stakeholders' importance based on power, urgency and legitimacy. Furthermore, stakeholder salience is constantly changing without a fixed property. Stakeholders can use political power, the foundation of alliance, etc. to change their relationships to companies and change the perceptive salience (Mitchell et al. 1997). Take power for example. Power is a relative concept that needs to comprehensively compare stakeholder and companies' resource capability. From a static point of view, a stakeholder holds the key resources that a company needs to survive and develop. This forces a company's reliance on stakeholders, increasing stakeholder power. If this stakeholder's needs are not satisfied, he may use power to control the inflow of key resources and force the company to do as he wants. From the dynamic point of view, if the company finds substitute resources or its self-capacity is gradually strengthened, the dependency on stakeholder would decrease and the stakeholder's power would also decrease. Therefore, the relationship between company and stakeholders is interdependent, dynamic and unfixed (Svendsen \& Laberge 2005). For private companies, the introduction of political connection will change managers' perception of stakeholders' relative importance and then influence companies' satisfaction of stakeholders' social responsibility requirement.

\section{Hypothesis development}

\section{Political connection and Corporate Social Responsibility}

Resource dependence theory holds that an organization is an open system and all resources that the organization's needs cannot be fulfilled internally; therefore, these needs must be met externally.. The more important, scarce and irreplaceable the required resources, the deeper dependence of the organization are on an external resource supplier (Pfeffer \& Salancik 1978). China is at the critical stage of economic transformation process, and government controls key resources companies need for survival and development Therefore, the government becomes the most significant source of dependence for

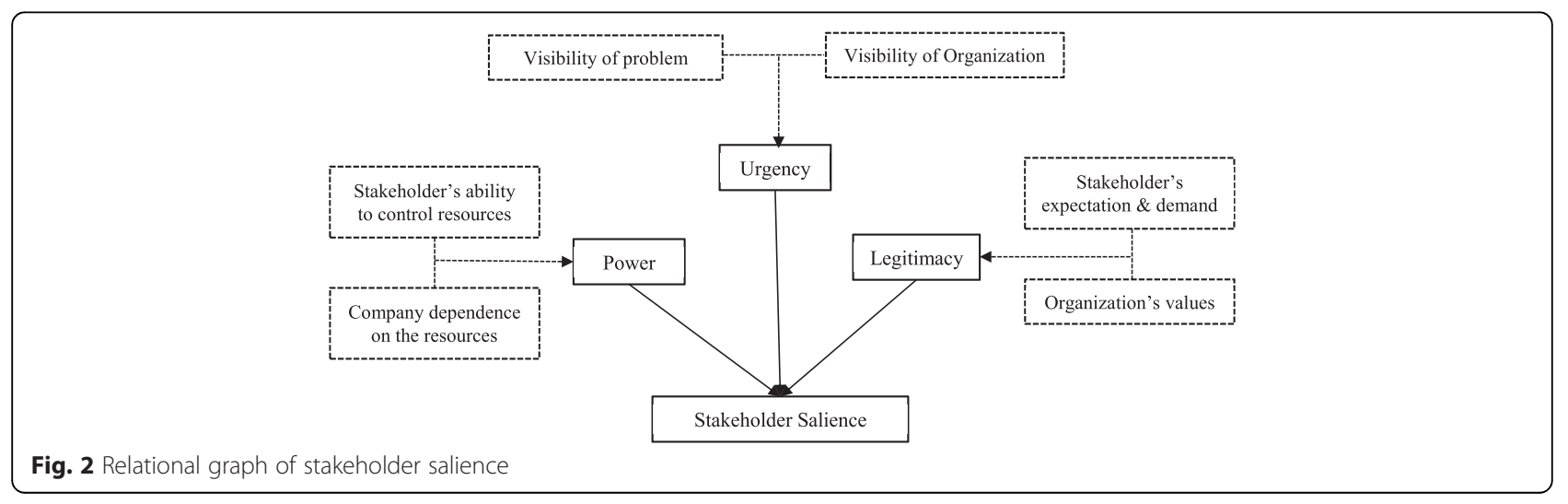


companies. Compared with state-owned companies with close ties to the government and foreign-funded companies supported by government, private companies are treated unjustly in terms of laws and regulations. They are at a disadvantage because of this. To achieve sustainable survival and development, companies should build good relationships with local governments actively and positively. Based on this relationship, companies could get preferential policies, like financing, tax preference, etc. and survive in a fierce market competition. Most government policies are made by officials. They will cooperate with interest groups due to an interest demand and share the rent, which is called political rent creation. Sometimes government officials will use the method of promulgating bad policies to an interest group to exchange benefits, which is called political rent extraction (McChesney 1987). Based on this theory, politically connected companies should pay for this relationship to meet government's needs when they accept preferential policies from the government. With economic development, government is paying more attention to companies' performance of social responsibility and issued relevant laws and regulations to address this. Faced with government's expectation, private companies will implement social responsibility to meet expectations. Hence, this paper makes the first hypothesis.

H1: Private companies' political connection has a positive influence on corporate social responsibility.

\section{Political connection and stakeholder-oriented responsibility}

CSR is critical for companies' production and development and is the foundation of sustainable development. Only performing social responsibility and coordinating stakeholders' relations can companies realize gradual improvement and strategic targets. However, due to enterprises' limited resources, companies cannot satisfy all stakeholders' needs. Donaldson and Perston (Donaldson \& Preston 1995) consider that not all stakeholders' requirements are reasonable. Therefore, companies should balance different stakeholders' requirements. According to stakeholder salience theory, companies and managers can justify different stakeholders' importance to them based on stakeholders' characteristics of legitimacy, urgency and power. Stakeholder salience is constantly changing without fixed properties. Stakeholders can use political power, and the foundation of alliance to change their image to companies and then change the perceptive salience (Mitchell et al. 1997). Therefore, the introduction of political connection will change managers' perception of stakeholders' relative importance and then influence companies' satisfaction to stakeholders' social responsibility requirement.
The following will discuss the detail relationship between political connection and stakeholder-oriented responsibility and make the second hypothesis.

\section{Society orientation}

Companies' society-oriented responsibility use donations as the principal thing, which is defined as funds or goods that are voluntarily provided for free to government or related organizations by companies (Financial Accounting Standards 1993). However, the reality of practice and definition is very different. Companies' beneficence is a purposive behavior to a large extent, which is called strategic philanthropy. Government has the function to maintain social stability, like helping refugees and vulnerable groups, which needs massive government spending and puts great pressure on public finances. Therefore, government needs to find a supplementary resource to remedy the lack of related investment. For politically connected companies, they would be willing to be the input-completer in order to improve government credibility, maintain the existing relationship with government and then get more key resources from the government. According to agency cost theory, managers need to obtain approval of the public and government, if they want to become an official. Carroll's Pyramid of CSR thinks that philanthropic responsibility is at the top of the pyramid, which can more easily get approval and is the important channel for managers to build and maintain political connection (Ma \& Parish 2006). Hence, this paper makes hypothesis $2 \mathrm{a}$.

H2a: Private companies' political connection has a positive influence on companies' contribution to society-oriented responsibility.

\section{Investor orientation}

As companies' main capital sponsor, investors are most concerned whether their capital will receive a corresponding return. Therefore, company's responsibility to investors is to create more profits, guarantee investors' capital safety, and pay dividends or interests on time. Political connection as an important social capital can improve companies' ability to obtain capital to reduce entry barriers, and then help to improve competitiveness and values (Hu 2006; Faccio et al. 2006; Wang \& Wu 2008). At the same time, political connection can strengthen controlling shareholders' dominance of the board of directors, restrain executives' opportunism behavior effectively, decrease the companies' overinvestment, and improve the efficiency of investment; thus, laying the foundation for attaining investment earnings (Chen \& Zhu 2009). When facing difficulty, politically connected companies may obtain more assistance from the government, which protects capital safety to some degrees (Sun et al. 2005; Yu \& Pan 2008). Hence, this paper makes hypothesis $2 \mathrm{~b}$. 
H2b: Private companies' political connection has a positive influence on companies' contribution to investor-oriented responsibility.

\section{Customer orientation}

From private companies' development history, one of the important reasons that they can compete with SOEs and foreign-funded enterprises without government support and become a new source of China's economic growth is to maintain a consumer service orientation. Companies' responsibility to consumers is a voluntary social responsibility. This can be communicated to the public with superior performance and a good social reputation, and then form competition superiority, which can also be a good way to build and maintain political connection. In recent years, product safety incidents have caught the attention of the government and consumers. Connected companies will be harmed more if they are linked to these safety concerns. Higher market share and better ability to enter barriers and obtain projects make politically connected companies invest more on consumers. Hence, this paper makes hypothesis 2c.

H2c: Private companies' political connection has a positive influence on companies' contribution to customer-oriented responsibility.

\section{Government orientation}

Companies' contribution to government-oriented responsibility can be measured by the actual tax burden. According to political cost hypothesis, government would implement stronger regulation on larger-scale enterprises and make them bear a higher tax burden (Zimmerman 1983). For politically connected companies, they always have a larger assets scale and draw higher attention from the media, government, and tax department than non-connected companies, which makes connected companies' tax position consistent with political cost hypothesis. However, according to political power hypothesis, larger-scale enterprises can obtain more resources and have a higher ability of revenue sharing and affect government's formulation of tax policy, which can help decrease companies' tax burden. Political connection can have the same influence as companies' scale to decrease the effective tax rate (Feng 2012). This paper agrees with political power hypothesis. According to China's reality of relation-based society, tax laws and regulations have a strong policybased characteristic and government has a strong ability to determine companies' payable taxes and tax preference, which makes officials' power to create rent. Politically connected companies will use their political resources to build a favorable tax environment. Hence, this paper makes hypothesis $2 \mathrm{~d}$.
H2d: Private companies' political connection has a negative influence on companies' contribution to government-oriented responsibility.

\section{Employee orientation}

Companies' contribution to employee-oriented responsibility states that companies should provide competitive wages and good benefits, ensure employees' safety, and provide abundant opportunities for employees' growth and development. However, some researchers found that political connection will cause companies' moral cost. Politically connected companies will use Guanxi to bypass labor protection laws and regulations to decrease cost and increase profit (Fan et al. 2007), which may cause a higher death rate than non-connected companies (Fisman \& Wang 2015). In recent years, labors' income compared to the national income has decreased. China's labor market is in buyer's monopoly situation and dispersive labors are in a weak position when negotiating with employers, which makes companies' tendency to reduce the investment in employees. For connected companies, political connection makes them have more channels to get resources and then decrease their attention on employees. Meanwhile, behavior of rent contribution may decrease the investment to employees. Hence, this paper makes hypothesis 2e.

H2e: Private companies' political connection has a negative influence on companies' contribution to employee-oriented responsibility.

\section{Method}

\section{Data sources}

In 2008, the Guidelines for Central Enterprises to Fulfill Social Responsibilities issued by SASAC and the Announcement about Strengthening Listed Companies' Performance of Social Responsibility issued by the Shanghai Stock Exchange symbolized a new stage in Chinese CSR. Therefore, this paper uses the year of 2008 as a starting-point and chooses A-share listed private companies during 2008-2014 as original samples to make the empirical test.

Executives' background materials are from Private Listed Companies' Database in CSMAR and political connection data is manually collected through these executives' resumes. Data of the institutional environment is from China's Marketization Index (2015) published by Fan and Wang. Data to calculate CSR are from the annual reports. Other financial data are from Wind.

This paper screens out some unsuitable samples based upon the following principles. (1) All financial companies including bank, securities, insurance, etc. are excluded because their substantial difference with non-financial companies. (2) Samples are excluded 
when executives' information is not clear, main operation income is vanishing, total assets are zero, or owner's equity is negative. (3) Listed companies that are specially treated as ST and "ST are excluded. (4) In order to avoid IPO effect, sample firms listed in and after 2008 are excluded. Lastly, this empirical research has 2590 samples of 370 listed private companies in 7 years.

According to Industry Classification Benchmark published by the China Securities Regulatory Commission in 2002, the sample companies' industrial distribution is shown in Table 8, and companies in the manufacturing industry, real estate industry and wholesale and retail trade industry occupy the first three positions.

\section{Dependent variables: CSR}

In the literature review part, we have summarized different methods to calculate CSR. Based on existing results and figures' quantity and availability, this paper chose content analysis method to measure companies' contribution to investor, consumer, employee, government and society's required responsibility from companies' expenses perspective.

\section{Society orientation}

Companies' responsibility to society mainly means whether companies contribute their benefits to society during daily production and management. Therefore, this index selects the donation, sponsorship fee, environmental expenditure, etc. in non-business expenditure part of the annual report. The ratio of these figures' sum

Table 8 Industry distribution of sample companies

\begin{tabular}{lll}
\hline Industry & Number & Proportion \\
\hline Mining Industry & 10 & $2.70 \%$ \\
$\quad$ Electricity, Heat, Gas and Water Production & 3 & $0.81 \%$ \\
and Supply Industry & 34 & $9.19 \%$ \\
Real Estate & 11 & $2.97 \%$ \\
Construction Industry & 2 & $0.54 \%$ \\
Scientific Research and Technological Services & 2 & $1.89 \%$ \\
Agriculture, Forestry, Husbandry and Fishery & 7 & $8.38 \%$ \\
Wholesale and Retail Trade & 31 & $0.27 \%$ \\
Water Resources, Environment and Public & 1 & \\
Facilities Management & & $0.27 \%$ \\
Health and Social Work & 1 & $0.81 \%$ \\
Culture, Sports and Entertainment & 3 & $4.32 \%$ \\
Information Transmission, Software and & 16 & \\
Information Technology Services & & $64.86 \%$ \\
Industry & 240 & $0.27 \%$ \\
Hotels and Catering Services & 1 & $1.62 \%$ \\
Comprehensive Industry & 6 & $1.08 \%$ \\
Renting and Commercial Services & 4 &
\end{tabular}

to prime operating revenue is a measure of companies' fulfilled degree to society. The higher the ratio, the better the companies' society-oriented performance.

$$
\begin{aligned}
\text { Society Orientation }= & \left(\begin{array}{l}
\text { Donation }+ \text { Sponsorship Fee } \\
+ \text { Funds }+ \text { Environmental Expenditure }
\end{array}\right) \\
& * \mathbf{1 0 0 0 0} / \text { Prime Operating revenue }
\end{aligned}
$$

Companies' responsibility to employees includes providing competitive wages and good benefits, ensuring employees' safety, and providing abundant opportunities for employees' growth and development. This paper chooses cash paid to employee and for employee and calculates the ratio of this index to prime operating revenue as the measurable indicator of companies' fulfilled degree to employee. The higher the ratio, the better the companies' employee-oriented performance.

$\begin{aligned} \text { Employee Orientation }= & \text { Cash Paid to Employee and for Employee } \\ & / \text { Prime Operating Revenue }\end{aligned}$

\section{Investor orientation}

Company's responsibility to investors is to create more profits, guarantee investors' capital safety, and pay dividends or interests on time. This paper chooses cash paid as dividend and interest and calculate the ratio of this index to prime operating revenue as the measurable indicator of companies' fulfilled degree to investor. The higher the ratio, the better the companies' investor-oriented performance.

\section{Investor Orientation $=$ Dividend and Interest Paid in Cash / Prime Operating Revenue}

\section{Customer orientation}

Companies should perform their responsibility to consumers, which includes the rational investment in $R \& D$, production, sales and after-sales, etc. according to consumers' requirement in the daily production activity. Based on past researches, companies' investment in consumer-oriented responsibility can be measured by prime operating cost, the ratio of this to prime operating revenue can be used as the measurable indicator of companies' fulfilled degree to consumer. The higher the ratio, the better the companies' consumeroriented performance.

\section{Customer Orientation $=$ Prime Operating Cost / Prime Operating Revenue}

\section{Government orientation}

Companies should perform their responsibility to government, which contains the compliance of laws and regulations, and the payment of taxes on time. This 
paper chooses actual paid taxes and the ratio of this index to prime operating revenue as the measurable indicator of companies' fulfilled degree in government. The higher the ratio, the better the companies' government-oriented performance.

\section{Government Orientation $=$ Actual Paid Taxes / Prime Operating Revenue}

\section{Aggregative indicator of CSR}

As the whole CSR is not this paper's research focus, so I chose the measurement method based on government's formula, which neglect the proportion of each stakeholder. The formula I chose is the social contribution rate given by China's Ministry of Finance in 1995.

\section{Social Contribution Rate $=$ Amount of Social Contribution / Average Total Asset}

Many scholars use and improve this above formula. As aforementioned, Cheng (1995) used the sales income instead of total average assets to make it more fit for companies' social achievements. Chen and Ma (2005) used the data based on cash system of accounting instead of the numerator based on accrual basis to make the formula attract more users' attention. Based on these scholars, we can get the following CSR measuring formula.

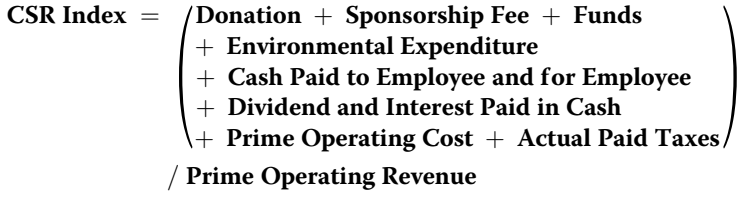

\section{Independent variables: political connection}

In literature review part, we have summarized diverse methods to measure political connection. Combined with China's national condition and the availability of data, this paper uses dummy variable method and considers that if chairman of the board or general manager is or was government official, NPC delegates, CPPCC delegates, Party Congress delegates, et al., political connection equals to 1 . If not, political connection equals to 0 .

\section{Control variables}

Combining existing researches, this paper chooses company scale, financial efficiency, duality, company growth and fixed asset ratio, and also controls for year and industry's effect.

Company scale has an important influence on CSR. Gainet (Gainet 2011) found that in the European market company scale has a positive effect on CSR. However, Deng \& Dart (1999) held that middle- and small-sized enterprises would be more inclined to respond stakeholders' needs quickly to get more developing opportunities because they received fewer resources than large enterprises . As a result, SMEs would invest more in CSR. This paper will use the logarithm of total assets to measure company scale. Many researchers consider that financial efficiency has a close relationship with CSR (Helwege et al. 2007). This paper uses return on assets (ROA) to measure financial efficiency. President's responsibility is to organize and supervise the companies' operation and production. General Manager's responsibility is to take charge of the specific operation and production. Researches show that duality would make the companies lack a balance mechanism that executives could make use of decision behavior to grab individual interests and potentially harm other stakeholders' interests (Wang et al. 2015). To measure duality, this paper uses the dummy variable method. If there exists a duality situation, it equals to 1 . If not, it equals to 0 . From the growth perspective, companies would make different choices in investing and distributing profits in different development periods. For example, companies in growth period prefer to choose investing instead of sharing profits. This paper chooses revenue growth rate to measure company growth. From a fixed asset ratio perspective, the higher index means that companies invest more on fixed asset and then reduce companies' cash flow and influence their CSR investment.

The following Table 9 summarizes all variables.

\section{Model design}

To test the two hypotheses, this paper uses the following regression models. To solve endogenous of political connection, company scale, financial efficiency and CSR, I use the first-lagged method (Lin et al. 2014).

H1:

$$
\begin{aligned}
C S R= & \alpha_{0}+\alpha_{1} P O L C_{t-1}+\alpha_{2} S I Z E_{t-1}+\alpha_{3} R O A_{t-1} \\
& +\alpha_{4} D U A L+\alpha_{5} G R O W+\alpha_{6} F I X+\alpha_{7} Y E A R \\
& +\alpha_{8} I N D
\end{aligned}
$$

$\mathrm{H} 2$ :

$$
\begin{aligned}
& \text { SOCO/GOVO/INVO/EMPO/CUSO } \\
& \begin{aligned}
= & \alpha_{0}+\alpha_{1} P O L C_{t-1}+\alpha_{2} S I Z E_{t-1}+\alpha_{3} R O A_{t-1} \\
& +\alpha_{4} D U A L+\alpha_{5} G R O W+\alpha_{6} F I X \\
& +\alpha_{7} Y E A R+\alpha_{8} I N D
\end{aligned}
\end{aligned}
$$

\section{Empirical analysis \\ Descriptive statistics}

Table 10 lists samples' political connection information. For overall samples, the non-political connected samples are dominant and political connected samples only occupy $26.06 \%$ of the total. However, as time goes by, the number of political connected samples continues to rise. 
Table 9 Definition and explanation of variables

\begin{tabular}{|c|c|c|c|}
\hline Type & Name & Code & Description \\
\hline \multirow[t]{6}{*}{ Dependent Variables } & CSR & CSR & $\begin{array}{l}\text { (Donation + Sponsorship Fee + Funds + Environmental Expenditure + } \\
\text { Cash Paid to Employee and for Employee + Dividend and Interest Paid } \\
\text { in Cash + Prime Operating Cost + Actual Paid Taxes) / Prime Operating } \\
\text { Revenue }\end{array}$ \\
\hline & Society Orientation & SOCO & $\begin{array}{l}\text { (Donation + Sponsorship Fee + Funds + Environmental } \\
\text { Expenditure)*10,000 / Prime Operating Revenue }\end{array}$ \\
\hline & Employee Orientation & EMPO & Cash Paid to Employee and for Employee / Prime Operating Revenue \\
\hline & Investor Orientation & INVO & Dividend and Interest Paid in Cash / Prime Operating Revenue \\
\hline & Customer Orientation & CUSO & Prime Operating Cost/ Prime Operating Revenue \\
\hline & Government Orientation & GOVO & Actual Paid Taxes/ Prime Operating Revenue \\
\hline Independent Variables & Political Connection & POLC & $\begin{array}{l}\text { If chairman of the board or general manager is or had been } \\
\text { government official, NPC delegates, CPPCC delegates, Party Congress } \\
\text { delegates, et al., POLC equals to } 1 \text {. If not, POLC equals to } 0 \text {. }\end{array}$ \\
\hline \multirow[t]{7}{*}{ Control Variables } & Company Scale & SIZE & Log (Total Asset) \\
\hline & Financial Efficiency & $\mathrm{ROA}$ & $\mathrm{ROA}$ \\
\hline & Duality & DUAL & $\begin{array}{l}\text { If the general manager and chairman is one person, DUAL equals to } 1 . \\
\text { If not, Dual equals to } 0 \text {. }\end{array}$ \\
\hline & Company Growth & GROW & The growth rate of main operation income \\
\hline & Fixed Asset Ratio & FIX & Fix Asset/ Total Asset \\
\hline & Year & YEAR & 7 year, Dummy Variable \\
\hline & Industry & IND & 15 industries, according to CSRC's industry classification standard (2012) \\
\hline
\end{tabular}

From whole set, the mean of CSR is 1.001, the minimum value is 0.396 and the maximum value is 3.816. According to the five core stakeholders we chose, companies invest the most in customer orientation, which is higher than the other four stakeholders' orientation. When divided into connected and non-connected samples, through comparing the average, we can see that connected samples' CSR performance is better than non-connected samples'. A similar situation is found in samples' investment in society, investor, and customer's responsibility. For the investment to employee and government, nonconnected samples' performance is better than connected samples'. Based on descriptive statistics, the results are consistent with $\mathrm{H} 1$ and $\mathrm{H} 2$ (Table 11).

Table 10 Descriptive statistics of samples by year

\begin{tabular}{cllll}
\hline Year & \multicolumn{2}{l}{ Non-political Connection } & \multicolumn{2}{l}{ Political Connection } \\
\hline 2008 & 277 & $74.86 \%$ & 93 & $25.14 \%$ \\
2009 & 277 & $74.86 \%$ & 93 & $25.14 \%$ \\
2010 & 273 & $73.78 \%$ & 97 & $26.22 \%$ \\
2011 & 273 & $73.78 \%$ & 97 & $26.22 \%$ \\
2012 & 272 & $73.51 \%$ & 98 & $26.49 \%$ \\
2013 & 272 & $73.51 \%$ & 98 & $26.49 \%$ \\
2014 & 271 & $73.24 \%$ & 99 & $26.76 \%$ \\
Total & 1915 & $73.94 \%$ & 675 & $26.06 \%$ \\
\hline
\end{tabular}

For control variables, connected companies' company scale and financial efficiency are higher than nonconnected companies'. The opposite situation exists for fixed asset ratio and companies' growth rate (Table 12).

\section{Correlation analysis}

To avoid multicollinearity problem, this paper uses Pearson two-tailed test to test the correlation among different variables.

For dependent variables, they are correlated at $1 \%$ significance level and the coefficients are relatively high; however, they are not higher than $50 \%$. For other variables, most of them are correlated at $10 \%$ or under the significance level and the coefficients are relatively low, the highest of which is $13 \%$ (Table 13).

\section{Regression analysis on political connection and CSR}

Based on the characteristics of samples, this paper chose pooled least squares method because the period of time is relatively short, just 7 years, and the independent variable, political connection, and range ability is relatively small. Meanwhile, in the test, there exists heteroskedasticity and this paper will use robust method to solve heteroskedasticity and later will announce robust standard error.

Regression results for $\mathrm{H} 1$ and $\mathrm{H} 2$ are shown below.

From Table 14, for CSR connected private companies' performance is better than non-connected private companies' at $1 \%$ significance level and H1 is supported. From control variables, company scale and duality do not 
Table 11 Descriptive statistics of the dependent variables

\begin{tabular}{|c|c|c|c|c|c|c|c|c|c|c|c|c|}
\hline & \multicolumn{4}{|c|}{ Samples } & \multicolumn{4}{|c|}{ Political Connection } & \multicolumn{4}{|c|}{ Non-political Connection } \\
\hline & Mean & SD & MIN & MAX & Mean & SD & MIN & MAX & Mean & SD & MIN & MAX \\
\hline CSR & 1.001 & 0.433 & 0.396 & 3.816 & 1.061 & 0.457 & 0.396 & 3.816 & 0.980 & 0.423 & 0.396 & 3.816 \\
\hline SOCO & 6.597 & 12.714 & 0.000 & 81.619 & 8.515 & 15.174 & 0.000 & 81.619 & 5.845 & 11.528 & 0.000 & 81.619 \\
\hline EMPO & 0.111 & 0.095 & 0.006 & 0.540 & 0.094 & 0.082 & 0.006 & 0.540 & 0.117 & 0.099 & 0.006 & 0.540 \\
\hline INVO & 0.054 & 0.062 & 0.000 & 0.410 & 0.060 & 0.069 & 0.000 & 0.410 & 0.052 & 0.059 & 0.000 & 0.410 \\
\hline CUSO & 0.733 & 0.178 & 0.165 & 1.065 & 0.744 & 0.169 & 0.165 & 1.065 & 0.729 & 0.180 & 0.165 & 1.065 \\
\hline GOVO & 0.071 & 0.081 & -0.047 & 0.563 & 0.070 & 0.089 & -0.047 & 0.563 & 0.071 & 0.078 & -0.047 & 0.563 \\
\hline
\end{tabular}

significantly influence CSR. Financial efficiency, company growth rate, and fixed asset ratio are negatively related to CSR at $1 \%$ significance level. High return on assets and company growth rate mean that companies can make good use of assets and make high profit to receive rapid growth. To maintain and improve the current level, companies will invest more money on the daily operation or investing opportunities. The high fixed asset ratio means that companies invest more on fixed asset and then reduce companies' cash flow and impact their CSR investment.

For society-oriented responsibility, connected companies' contribution is higher than non-connected private companies' at $1 \%$ significance level. $\mathrm{H} 2 \mathrm{a}$ is supported in that private companies' political connection has a positive influence on companies' contribution to society-oriented responsibility. As control variables, company scale, duality, and company growth rate do not have significant influence, which is partially true because companies have not formed long-term strategic charity plan and most contribute to emergencies with great influence (Wang 2013). From a descriptive statistics part, we can see that companies' performance of society orientation is highest in 2008. Furthermore, private companies' philanthropic responsibility is closely related to entrepreneurs' self-value and experience. The above two reasons can also be used to explain the relatively low R2.

For investor-oriented responsibility, political connection's coefficient is 0.0017 and not significant, which means political connection does not have significant influence and H2b is unsupported. So there is no significant relationship between political connection and investor-oriented responsibility.
For customer-oriented responsibility, connected companies' contribution is higher than non-connected private companies' at $10 \%$ significance level. $\mathrm{H} 2 \mathrm{c}$ is supported in that private companies' political connection has a positive influence on companies' contribution to customer-oriented responsibility.

For government-oriented responsibility, connected companies' contribution is lower than non-connected private companies' at $10 \%$ significance level. $\mathrm{H} 2 \mathrm{~d}$ is supported in that private companies' political connection has a negative influence on companies' contribution to government-oriented responsibility. This result supports the political power hypothesis.

For employee-oriented responsibility, connected companies' contribution is lower than non-connected private companies' at $1 \%$ significance level. $\mathrm{H} 2 \mathrm{e}$ is supported in that private companies' political connection has a negative influence on companies' contribution to employeeoriented responsibility, which supports that political connection will cause companies' moral cost.

\section{Regression results on political connection and CSR}

From Table 15, political connection has a positive influence on CSR. However, when CSR is divided by stakeholders, politically connected companies' performance is not better than non-political connected companies' in any aspect. Companies will judge differently to satisfy stakeholders' requirement according to their perception of stakeholders' importance (Table 16).

Table 12 Descriptive statistics of the control variables

\begin{tabular}{|c|c|c|c|c|c|c|c|c|c|c|c|c|}
\hline & \multicolumn{4}{|l|}{ Sample } & \multicolumn{4}{|c|}{ Political Connection } & \multicolumn{4}{|c|}{ Non-political Connection } \\
\hline & MEAN & SD & MIN & MAX & MEAN & SD & MIN & MAX & MEAN & SD & MIN & MAX \\
\hline SIZE & 21.494 & 1.168 & 18.474 & 24.586 & 21.734 & 1.172 & 18.474 & 24.586 & 21.410 & 1.155 & 18.474 & 24.586 \\
\hline $\mathrm{ROA}$ & 0.065 & 0.069 & -0.161 & 0.338 & 0.069 & 0.064 & -0.161 & 0.338 & 0.064 & 0.070 & -0.161 & 0.338 \\
\hline DUAL & 0.229 & 0.420 & 0.000 & 1.000 & 0.187 & 0.390 & 0.000 & 1.000 & 0.244 & 0.429 & 0.000 & 1.000 \\
\hline FIX & 0.221 & 0.154 & 0.001 & 0.654 & 0.213 & 0.154 & 0.001 & 0.654 & 0.224 & 0.154 & 0.001 & 0.654 \\
\hline GROW & 0.244 & 0.938 & -0.796 & 7.766 & 0.241 & 0.937 & -0.796 & 7.766 & 0.244 & 0.939 & -0.796 & 7.766 \\
\hline
\end{tabular}


Table 13 Correlation analysis

\begin{tabular}{|c|c|c|c|c|c|c|c|c|c|c|c|c|c|}
\hline & CSR & SOCR & CUSO & EMPO & GOVO & INVO & POLC & INS & SIZE & $\mathrm{ROA}$ & DUAL & FIX & GROW \\
\hline CSR & 1 & & & & & & & & & & & & \\
\hline SOCR & $0.137^{* * *}$ & 1 & & & & & & & & & & & \\
\hline CUSO & $0.130^{* * *}$ & $-0.216^{* * *}$ & 1 & & & & & & & & & & \\
\hline EMPO & $0.192^{* * *}$ & $0.080^{* * *}$ & $-0.282^{* * *}$ & 1 & & & & & & & & & \\
\hline GOVO & $0.414^{* * *}$ & $0.282^{* * *}$ & $-0.441^{* * *}$ & $0.230^{* * *}$ & 1 & & & & & & & & \\
\hline INVO & $0.424^{* * *}$ & $0.166^{* * *}$ & $-0.208^{* * *}$ & $0.126^{* * *}$ & $0.449^{* * *}$ & 1 & & & & & & & \\
\hline POLC & $0.067^{* * *}$ & $0.100^{* * *}$ & $0.037^{*}$ & $-0.119^{* * *}$ & -0.010 & $0.045^{* *}$ & 1 & & & & & & \\
\hline INS & -0.015 & $-0.042^{*}$ & $0.043^{* *}$ & $-0.040^{* *}$ & $-0.102^{* * *}$ & $-0.058^{* * *}$ & -0.010 & 1 & & & & & \\
\hline SIZE & $0.045^{* *}$ & 0.003 & $0.083^{* * *}$ & $-0.293^{* * *}$ & $0.044^{* *}$ & $0.278^{* * *}$ & $0.124^{* * *}$ & $0.062^{* * *}$ & 1 & & & & \\
\hline $\mathrm{ROA}$ & $-0.079^{* * *}$ & $0.082^{* * * *}$ & $-0.299^{* * *}$ & -0.024 & $0.117^{* * *}$ & 0.019 & 0.033 & $0.063^{* * *}$ & $0.109^{* * *}$ & 1 & & & \\
\hline DUAL & 0.008 & -0.004 & -0.019 & $0.081^{* * *}$ & -0.010 & -0.031 & $-0.062^{* * *}$ & $0.061^{* * *}$ & $-0.122^{* * *}$ & -0.001 & 1 & & \\
\hline FIX & $-0.271^{* * *}$ & $-0.089^{* * *}$ & $0.176^{* * *}$ & -0.026 & $-0.269^{* * *}$ & $-0.176^{* * *}$ & $-0.033^{* * *}$ & $-0.079^{* * *}$ & $-0.058^{* * *}$ & $-0.112^{* * *}$ & 0.025 & 1 & \\
\hline GROW & $-0.048^{* *}$ & -0.010 & $-0.078^{* * *}$ & $-0.110^{* * *}$ & -0.020 & $-0.089^{* * *}$ & 0.006 & -0.014 & $-0.130^{* * *}$ & $-0.041^{* *}$ & 0.007 & $-0.076^{* * *}$ & 1 \\
\hline
\end{tabular}

$* * * P<0.01$
$* * P<0.05$

${ }^{*} P<0.1$

Based on stakeholder salience theory, companies can determine the salience through stakeholders' legitimacy, urgency, and power.

For politically connected companies, after their connection with the government, government's salience increases. From power's perspective, connected companies' dependence on key resources controlled by government increases and then the relative power also increases. From urgency's perspective, government influences companies and make its requirements and problems seen easily by companies and government can also use key resources to threaten companies to increase authority. For government, it does not only ask companies to pay taxes on time, but also needs them to help solve problems, which cannot

Table 14 Regression results of $\mathrm{H} 1$ and $\mathrm{H} 2$

\begin{tabular}{|c|c|c|c|c|c|c|}
\hline & CSR & SOCO & INVO & CUSO & GOVO & EMPO \\
\hline Hypotheses & $\mathrm{H} 1$ & $\mathrm{H} 2 \mathrm{a}$ & $\mathrm{H} 2 \mathrm{~b}$ & $\mathrm{H} 2 \mathrm{C}$ & $\mathrm{H} 2 \mathrm{~d}$ & $\mathrm{H} 2 \mathrm{e}$ \\
\hline \multirow[t]{2}{*}{$\overline{P O L C}$} & $0.058^{* * *}$ & $2.366^{* * *}$ & 0.002 & $0.014^{*}$ & $-0.006^{*}$ & $-0.014^{* * *}$ \\
\hline & $(0.019)$ & $(0.665)$ & $(0.002)$ & $(0.007)$ & $(0.003)$ & $(0.003)$ \\
\hline \multirow[t]{2}{*}{ SIZE } & -0.0120 & -0.459 & $0.011^{* * *}$ & $0.012^{* * *}$ & -0.002 & $-0.025^{* * *}$ \\
\hline & $(0.012)$ & $(0.288)$ & $(0.001)$ & $(0.003)$ & $(0.001)$ & $(0.002)$ \\
\hline \multirow[t]{2}{*}{$\mathrm{ROA}$} & $-0.567^{* * *}$ & $14.217^{* * *}$ & -0.000 & $-0.757^{* * *}$ & $0.139^{* * *}$ & -0.023 \\
\hline & $(0.212)$ & $(4.425)$ & $(0.021)$ & $(0.072)$ & $(0.031)$ & $(0.038)$ \\
\hline \multirow[t]{2}{*}{ DUAL } & 0.036 & 0.044 & 0.001 & 0.004 & -0.002 & 0.002 \\
\hline & $(0.023)$ & $(0.613)$ & $(0.003)$ & $(0.008)$ & $(0.004)$ & $(0.004)$ \\
\hline \multirow[t]{2}{*}{ GROW } & $-0.039^{* *}$ & -0.348 & $-0.006^{* * *}$ & $-0.013^{* *}$ & $-0.005^{* *}$ & $-0.015^{* * *}$ \\
\hline & $(0.016)$ & $(0.413)$ & $(0.001)$ & $(0.005)$ & $(0.002)$ & $(0.002)$ \\
\hline \multirow[t]{2}{*}{ FIX } & $-0.560^{* * *}$ & $-6.131^{* * *}$ & $-0.033^{* * *}$ & $0.111^{* * *}$ & $-0.087^{* * *}$ & -0.003 \\
\hline & $(0.071)$ & $(2.062)$ & $(0.009)$ & $(0.024)$ & $(0.013)$ & $(0.014)$ \\
\hline YEAR & Yes & Yes & Yes & Yes & Yes & Yes \\
\hline IND & Yes & Yes & Yes & Yes & Yes & Yes \\
\hline$R^{2}$ & $17.85 \%$ & $7.29 \%$ & $25.97 \%$ & $27.36 \%$ & $24.57 \%$ & $26.43 \%$ \\
\hline Observation & 2180 & 1790 & 2180 & 2180 & 2180 & 2180 \\
\hline
\end{tabular}

() Robust standard error 
Table 15 Test result of $\mathrm{H} 1$ and $\mathrm{H}_{2}$

\begin{tabular}{llll}
\hline Hypotheses & Dependent Variable & Content & Regression Result \\
\hline $\mathrm{H} 1$ & $\mathrm{CSR}$ & $\mathrm{PC}>\mathrm{NPC}$ & $\mathrm{PC}>\mathrm{NPC}\left(^{* * *}\right)$ \\
$\mathrm{H} 2 \mathrm{a}$ & $\mathrm{SOCO}$ & $\mathrm{PC}>\mathrm{NPC}$ & $\mathrm{PC}>\mathrm{NPC}\left(^{* * *}\right)$ \\
$\mathrm{H} 2 \mathrm{~b}$ & $\mathrm{NNVO}$ & $\mathrm{PC}>\mathrm{NPC}$ & $\mathrm{PC}>\mathrm{NPC}$ \\
$\mathrm{H} 2 \mathrm{C}$ & $\mathrm{CUSO}$ & $\mathrm{PC}>\mathrm{NPC}$ & $\mathrm{PC}>\mathrm{NPC}\left({ }^{*}\right)$ \\
$\mathrm{H} 2 \mathrm{~d}$ & GOVO & $\mathrm{PC}<\mathrm{NPC}$ & $\mathrm{PC}<\mathrm{NPC}\left({ }^{*}\right)$ \\
$\mathrm{H} 2 \mathrm{e}$ & EMPO & $\mathrm{PC}<\mathrm{NPC}$ & $\mathrm{PC}<\mathrm{NPC}\left(^{* * *}\right)$
\end{tabular}

$P C$ Political Connection, NPC Non-political Connection

${ }^{* * *} P<0.01$

${ }^{* *} P<0.05$

${ }^{*} P<0.1$

be totally solved by government and these problems mainly consist of society-oriented problems (Xin 2008). Carroll's Pyramid of CSR thinks that philanthropic responsibility is at the top of the pyramid, which can more easily get approval and is the important channel for managers to build and maintain political connection (Ma \& Parish 2006). Politically connected companies can use philanthropic investment to get more developing opportunities and tax preference from government in return. Therefore, compared with non-connected companies, connected companies will contribute more on societyoriented responsibility and less on government-oriented responsibility because of political power effect.

Employees, especially the talented, are essential to government's survival and development. They are the main producer and producer of products and service. The creativity and initiative of employees directly affected companies' level of competitiveness. They can use their resources to pressure companies to address their urgent requirements (Wang \& Zhang 2003). However, when a company builds a connection with the government, its selectable channels to obtain resources increase and employees' relative salience decreases because the relative power decreases and its urgency also decreases as employees' requirement is less visible by the company and managers. However, for unconnected companies, in order to survive and develop, it must broaden its appeal to talents and build core teams with higher skills, which means increasing the investment in employee and employee's salience to these unconnected companies.

For investors, as companies' direct capital supplier, they have a close connection with companies and have an important influence on companies' decision-making. They can use their capital to threaten companies and protect self-interests. For customers, as the direct creation of companies' profit, private companies keep customer service orientation and pay close attention to customers to compete with SOEs and foreign-funded enterprises without government support. When introducing political factors, connected companies will get more customer and media's attention. Their behavior of harming customers' benefit will be enlarged. Therefore, customers have more power and ability to affect companies,

Table 16 Robust Regression Result of $\mathrm{H} 1$ and $\mathrm{H}_{2}$

\begin{tabular}{|c|c|c|c|c|c|c|}
\hline & CSR & SOCO & INVO & CUSO & GOVO & EMPO \\
\hline Hypotheses & $\mathrm{H} 1$ & $\mathrm{H} 2 \mathrm{a}$ & $\mathrm{H} 2 \mathrm{~b}$ & $\mathrm{H} 2 \mathrm{C}$ & $\mathrm{H} 2 \mathrm{~d}$ & $\mathrm{H} 2 \mathrm{e}$ \\
\hline \multirow[t]{2}{*}{ POLC } & $0.017^{* * *}$ & $0.434^{* * *}$ & 0.001 & $0.005^{* * *}$ & $-0.002^{* *}$ & $-0.004^{* * *}$ \\
\hline & $(0.004)$ & $(0.158)$ & $(0.001)$ & $(0.001)$ & $(0.000)$ & $(0.000)$ \\
\hline \multirow[t]{2}{*}{ SIZE } & -0.013 & -0.467 & $0.011^{* *}$ & $0.011^{* * *}$ & -0.002 & $-0.025^{* * *}$ \\
\hline & $(0.011)$ & $(0.291)$ & $(0.001)$ & $(0.003)$ & $(0.001)$ & $(0.002)$ \\
\hline \multirow[t]{2}{*}{$\mathrm{ROA}$} & $-0.570^{* * *}$ & $14.295^{* * *}$ & -0.001 & $-0.757^{* * *}$ & $0.139^{* * *}$ & -0.022 \\
\hline & $(0.212)$ & $(4.418)$ & $(0.021)$ & $(0.072)$ & $(0.031)$ & $(0.038)$ \\
\hline \multirow[t]{2}{*}{ DUAL } & 0.036 & 0.021 & 0.000 & 0.004 & -0.002 & 0.002 \\
\hline & $(0.022)$ & $(0.617)$ & $(0.002)$ & $(0.008)$ & $(0.003)$ & $(0.004)$ \\
\hline \multirow[t]{2}{*}{ GROW } & $-0.039^{* *}$ & -0.339 & $-0.006^{* * *}$ & $-0.013^{* *}$ & $-0.005^{* *}$ & $-0.015^{* * *}$ \\
\hline & $(0.016)$ & $(0.415)$ & $(0.001)$ & $(0.005)$ & $(0.002)$ & $(0.002)$ \\
\hline \multirow[t]{2}{*}{ FIX } & $-0.564^{* * *}$ & $-6.326^{* * *}$ & $-0.033^{* * *}$ & $0.110^{* * *}$ & $-0.087^{* * *}$ & -0.001 \\
\hline & $(0.070)$ & $(2.069)$ & $(0.009)$ & $(0.024)$ & $(0.013)$ & $(0.014)$ \\
\hline YEAR & Yes & Yes & Yes & Yes & Yes & Yes \\
\hline IND & Yes & Yes & Yes & Yes & Yes & Yes \\
\hline$R^{2}$ & $17.94 \%$ & $6.86 \%$ & $26.00 \%$ & $27.44 \%$ & $24.67 \%$ & $26.44 \%$ \\
\hline Observation & 2180 & 1790 & 2180 & 2180 & 2180 & 2180 \\
\hline
\end{tabular}

() Robust standard error

${ }^{* * *} P<0.01$

${ }^{* *} P<0.05$

${ }^{*} P<0.1$ 
which increase their salience. In sum, politically connected companies' performance to customers is better than non-politically connected companies.

\section{Robust test}

To test the results' robustness, this paper changes the measurement of political connection. For political connection, this part makes use of the valuation method by giving the different levels numerical values. Political connection equals to 5 with national connection; equals to 4 with provincial connection; equals to 3 with municipal connection; equals to 2 with county-level connection; equals to 1 with township-level connection; and equals to 0 with no connection (Du et al. 2009; Wu et al. 2014).

For $\mathrm{H} 1$ and $\mathrm{H} 2$, besides the significance level of political connection's coefficients, customer orientation and government orientation increase, the other political connection's coefficients' sign and significance level do not change. From the regression results, when a company has a higher political connection level, it would contribution more to CSR and society-oriented and customeroriented responsibility, and less on employee-oriented and government-oriented responsibility.

From above analysis, this paper's regression model and results are robust.

\section{Conclusion}

This paper uses non-financial A-share listed private companies from 2008 to 2014 as samples and analyzes the influence of political connection on CSR under different stakeholder orientation. The paper finds that political connection has a positive influence on private companies' CSR (H1). However, if we divide the companies' social responsibility by diverse stakeholders, we find that $\mathrm{H} 1$ is valid for some certain stakeholderoriented responsibility, but for some other stakeholderoriented responsibility, $\mathrm{H} 1$ is not valid. The above results partially support $\mathrm{H} 2$ : political connected and nonpolitical connected companies will choose and satisfy a certain stakeholder preferentially according to the importance of stakeholders. The companies with political connection are significantly better than the ones without political connection at society-oriented and customersoriented responsibility. The two kinds of companies have no significant difference at investors-oriented responsibility. As for government-oriented and employeeoriented responsibility, the companies with political connection are worse than the ones without political connection. There are two reasons from the perspective of the dynamic stakeholder salience.

China is still facing many institutional environmental problems, which have a far-reaching influence on private companies. Private companies have faced unfair treatment for a long time and have no chance but to build political connections with government. It is more important for government to build a fair competitive environment and a sound legal system environment for private companies and guide them to establish a systematical social responsibility strategy. Specifically, improving the institutional environment and giving more attention to the relationship between the Chinese government and enterprises are necessary for an economic reform. Then, the government should guide private companies to establish social responsibility strategy, improve labors protection system and bargaining power, which help to crack down the "moral cost" issue caused by political connections. For companies, during the performance of corporate social responsibility, companies should distinguish the core stakeholders according to their own characteristics. Companies should know which stakeholder is most important and establish viable relationships to promote sustainable development.

Both CSR and stakeholders' theories are complicated academic theories. Researchers have different views. This paper inevitably has some limitations, reflected in the following several points. Firstly, this paper's design indicators for CSR are from a financial perspective. However, financial statements are disclosed by companies independently, which only reflects its operating and financial results. Consequently, it may be not comprehensive and objective enough to measure the performance of social responsibility. Secondly, this paper only considers political connections disclosed in executives' resume and neglects recessive political connections. Although this paper values and studies different levels of political connections, it does not distinguish government-type officials and delegate-type officials and then study the influence of different types of officials on the performance of corporate social responsibility.

Based on the above problems, further research can focus on the following points.

(1)Establish more comprehensive and objective indicators to measure the performance of corporate and stakeholders' social responsibility.

(2)Distinguish different types of political connections and discuss the influence of government-type political connections and delegate-type political connections on the performance of fulfilling stakeholdersoriented responsibility.

(3) The degree of importance of different stakeholders perceived by companies and the difference for companies to meet stakeholders' demand at various levels are reflected in corporate operating performance. Operating performance can be added in future research. Further research can test whether corporate choice's change brought by political connections will improve corporate performance, a more realistic significance. 


\section{Competing interests}

The authors declare that they have no competing interests.

\section{Authors' contributions}

$\mathrm{HH}$ suggested the concept and designed the framework for the paper while also performing the theoretical research. ZZ worked on the sample by collecting the data and conducting the empirical analysis. Both authors read and approved the final manuscript.

\section{Acknowledgements}

As reviewers of the paper, I suggest Manhong Mannie Liu of Renmin University of China and Lu Hualiang of Nanjing University of Finance \& Economic. Additionally, I would like to acknowledge the participation of Rene Schmidpeter of Cologne Business School for suggesting me to contribute a paper in this field. Please find their details enclosed in the submission portal.

\section{Author details}

${ }^{1}$ Peking University HSBC Business School, Room 736, University Town, Nanshan District, Shenzhen, Guangdong Province 518055, China. ${ }^{2}$ PHBS Center for Green Economy, Peking University HSBC Business School, Room 633, University Town, Nanshan District, Shenzhen, Guangdong Province 518055, China.

Received: 2 June 2016 Accepted: 11 June 2016

Published online: 16 August 2016

\section{References}

Agle, B. R., \& Sonnenfeld, J. A. (1999). Who matters to CEOs? An investigation of stakeholder attributes and salience, corporate performance, and CEO values. Academy of Management Journal, 42(5), 507-525.

Aguilera, R. V., Rupp, D. E., Williams, C. A., \& Ganapathi, J. (2007). Putting the s back in corporate social responsibility: a multilevel theory of social change in organizations. Academy of Management Review, 32(3), 836-863.

Barnea, A., \& Rubin, A. (2010). Corporate social responsibility as a conflict between shareholders. Journal of Business Ethics, 97(1), 71-86.

Boubakri, N., Cosset, J. C., \& Saffar, W. (2008). Political connections of newly privatized firms. Journal of Corporate Finance, 14(5), 654-673.

Cao, Y., \& Yu, L. (2013). Government control, corporate social responsibility and investment efficiency: samples of the listed companies during 2009-2011. China Reform, 7, 127-135.

Carroll, A. B. (1979). A three-dimensional conceptual model of social performance. Academy of Management Review, 4(4), 497-505.

Carroll, A. B. (1991). The pyramid of corporate social responsibility: toward the moral management of organizational stakeholders. Business Horizons, 34(4), 39-48.

Chen, Y., \& Ma, L. (2005). The empirical study of Chinese listed companies social responsibility accounting information's market reaction. Accounting Research, $11,76-81$.

Chen, Y., \& Zhu, S. (2009). Political connection, institutional environment and capital investment of listed companies. Journal of Financial Economics, 35(12), 27-39.

Cheng, A. (1995). The study of optimizing social contribution structure. Shanghai Statistics, 9, 13-14.

Clarkson, M. B. E. (1995). A stakeholder framework for analyzing and evaluating corporate social performance. Academy of Management Review, 20(20), 92-117.

Deng, J., \& Zeng, Y. (2009). Can political connection improve the performance of private enterprises? China Industrial Economics, 2, 98-108.

Deng, S., \& Dart, J. (1999). The market orientation of Chinese enterprises during a time of transition. European Journal of Marketing, 33(5/6), 631-654.

Donaldson, T., \& Preston, L. E. (1995). The stakeholder theory of the corporation: concepts, evidence, and implications. Academy of Management Review, 20(20), 65-91

Dong, D., Luo, Z. J., \& Wei, X. H. (2014). Employee benefits with Chinese characteristics: evidence from private firms in China. Preliminary Draft.

Du, X., Lei, Y., \& Guo, J. (2009). Political connection, types of political connections and accounting conservatism of private listed companies. China Industrial Economics, 7, 87-97.

Edward, R., \& Freeman. (1994). The politics of stakeholder theory: some future directions. Business Ethics Quarterly, 4(4), 409-421.

Faccio, M. Masulis, R. W. \& Mcconnell, J. J. (2006). Political connections and corporate bailouts. Journal of Finance, 61(6), 2597-2635.
Faccio, M., \& Parsley, D. C. (2007). Sudden deaths: taking stock of geographic ties. Journal of Financial and Quantitative Analysis, 44(3), 683-718.

Faccio, M., \& Parsley, D. C. (2009). Sudden Deaths: Taking Stock of Political Connections. C.E.P.R. Discussion Papers.

Fan, J. P. H., Wong, T. J., \& Zhang, T. (2007). Politically connected CEOs, corporate governance, and post-IPO performance of China's newly partially privatized firms. Journal of Financial Economics, 84(2), 330-357.

Feng, Y. (2012). A study on the relationship between political connections and tax burden of Chinese private enterprises. Management Review, 24(6), 167-176.

Fisman, R. (2001). Estimating the value of political connections. General Information, 91(4), 1095-1102.

Fisman, R., \& Wang, Y. (2015). The mortality cost of political connections. Review of Economic Studies, 82, 4

Francis, B. B., Hasan, I., \& Sun, X. (2009). Political connections and the process of going public: evidence from china. Journal of International Money and Finance, 28(4), 696-719.

Gainet, C. (2011). Exploring the impact of legal systems and financial structure on corporate responsibility. Journal of Business Ethics, 95 (2 Supplement), 195-222.

Gao, J. \& Peng. S. (2011). The evaluation of the fulfillment of corporate social responsibility - based on the dynamic corporate social responsibility view. Proceedings of Chinese accounting association meeting 2011.

Gao, J., \& Zhou, X. (2008). Operating performance, ultimate controller and degree of social responsibility fulfillment. Collected Essays on Finance and Economics, $6,63-69$

Godfrey, P. C. (2005). The relationship between corporate philanthropy and shareholder wealth: a risk management perspective. Academy of Management Review, 30(4), 777-798.

Goel, A. M., \& Thakor, A. V. (2008). Overconfidence, CEO Selection, and Corporate Governance. Journal of Finance, 63, 2737-2784

Goldman, E., Rocholl, J., \& So, J. (2006). Does political connectedness affect firm value? Ssrn Electronic Journal, 21(4), 1607-1652(46).

Gompers, P., Ishii, J., \& Metrick, A. (2003). Corporate governance and equity prices. Quarterly Journal of Economics, 118(1), 107-155

Greenley, G. E., \& Foxall, G. R. (1998). External moderation of associations among stakeholder orientations and company performance. International Journal of Research in Marketing, 15(1), 51-69.

Gu, L. (2015). The current situation of CSR from perspective of Chinese companies CSR blue book. http://www.csrworld.cn/article-4872-1.html.

Helwege, J., Pirinsky, C., \& Stulz, R. M. (2007). Why do firms become widely held? an analysis of the dynamics of corporate ownership. Journal of Finance, 62(3), 995-1028.

$\mathrm{Hu}, \mathrm{X}$. (2006). Political identity of private entrepreneurs and the convenience of financing —evidence from the top 100 private companies in Zhejiang. Management World, 5, 107-113.

Huang, Q., Peng, H., Zhong, H., Zhang, C. (2014). Research Report on Corporate Social Responsibility of China. Social Science Documentation Publishing House Press.

Jenkins, H. (2006). Small business champions for corporate social responsibility. Journal of Business Ethics, 67(3), 241-256.

Jia, M., \& Zhang, Z. (2010). Does political connection influence corporate philanthropy? Management World, 4, 99-113.

Krueger, A. O. (1974). The political economy of the rent-seeking society. American Economic Review, 64(64), 291-303.

Li, S. (2010). Institutional environments, political relationship and corporate donation. China Accounting Reviews, 2, 161-178.

Li, S., Fetscherin, D. M., Alon, I., Lattemann, C., \& Yeh, K. (2010). Corporate social responsibility in emerging markets: the importance of the governance environment. Mir Management International Review. Journal of International Business Studies, 50(5), 635-654.

Li, Z. (2006). A study on relation of corporate social responsibility and corporate value: empirical evidence from Shanghai securities exchange. China Industrial Economy, 2, 77-83.

Lian, Y. (2014). Report on Chinese Social Opinion and Crisis Management. Contemporary China Publishing House.

Lin, K. J., Tan, J., Zhao, L., \& Karim, K. (2014). In the name of charity: political connections and strategic corporate social responsibility in a transition economy. Journal of Corporate Finance, 32, 327-346.

Luo, D., \& Huang, N. (2008). Political relationship and firm value of private company. Journal of Management Sciences, 21(6), 21-28.

Ma, D \& Parish, W. L (2006). Tocquevillian moments: charitable contributions by Chinese private entrepreneurs. Social Forces, 85(2), 943-964. 
Maignan, I., \& Ralston, D. A. (2002). Corporate social responsibility in Europe and the U.S.: insights from businesses' self-presentations. Journal of International Business Studies, 33(3), 497-514.

McChesney, F. S. (1987). Rent extraction and rent creation in the economic theory of regulation. The Journal of Legal Studies, 16(1), 179-196.

Mian, A., \& Khwaja, A. I. (2005). Do lenders favor politically connected firms? rent provision in an emerging financial market. Social Science Electronic Publishing, 120(4), 1371-1411.

Mitchell, R. K., Agle, B. R., \& Wood, D. J. (1997). Toward a theory of stakeholder identification and salience: defining the principle of who and what really counts. Academy of Management Review. Academy of Management Review, 22(4), 853-886.

Perrini, F., Russo, A., \& Tencati, A. (2007). CSR strategies of SMEs and large firms: evidence from Italy. Journal of Business Ethics, 74(3), 285-300.

Pfeffer, J., \& Salancik, G. R. (1978). The external control of organizations: a resource dependence perspective. The Economic Journal, 4, 2.

Qiu, D., \& Xu, L. (2015). TMT's political connections of private capital and corporate social responsibility performance-Based on Data of SME board. Soft Science, 1, 11-14.

Sánchez, C. M. (2000). Motives for corporate philanthropy in el salvador: altruism and political legitimacy. Journal of Business Ethics, 27(4), 363-375.

Shen, H., \& Shen, Y. (2003). The overall combination trend of corporate social responsibility and stakeholder theory. Economic Issues in China, 2, 51-60.

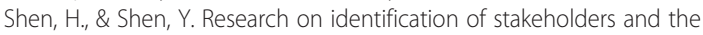
weight-based on financial report. Economic Management. 2004;(10).

$\mathrm{Su}$, J., \& He, J. (2009). Does giving lead to getting? evidence from chinese private enterprises. Journal of Business Ethics, 93(1), 73-90.

Su, X., \& Zhong, W. (2011). The differences of CSR motives and policy meaning: a firm nature perspective. The Theory and Practice of Finance and Economics, 32(1), 83-86

Sun, Z., Liu, F., \& Li, Z. (2005). Market development, government influence and corporate debt maturity structure-evidence from China's listed companies. Economic Research, 5, 52-63.

Sun, X. Empirical study on the influence of China's private listed companies' political connection on excessive investment. Southwestern University of Finance and Economics; 2012.

Svendsen, A. C., \& Laberge, M. (2005). Convening stakeholder networks. Journal of Corporate Citizenship, 2005(September), 91-104(14).

Swanson, D. L. (1995). Addressing a theoretical problem by reorienting the corporate social performance model. Academy of Management Review, 20(1), 43-64.

Waddock, S. A., \& Graves, S. B. (2009). The corporate social performance-financial performance link. Strategic Management Journal, 16(2), 61-78.

Wang, S. (2013). Characteristics and development countermeasures of China's private enterprises of charitable giving. Economic \& Trade Update, 1, 8-9.

Wang, L., \& Zhang, L. (2003). Stakeholders' impact on the success of corporate strategy. Economic Management, 14, 33-37.

Wang, Q., \& Wu, S. (2008). Political connection's impact on company performance - based on China's listed companies' political influence index. International Symposium on Empirical Accounting in China.

Wang, M., Guo, Q., \& Guo, S. (2015). Research on CSR's influence factors of listed companies-based on corporate internal governance view. Special Zone Economy, 4, 55-59.

Williamson, D., Lynch-Wood, G., \& Ramsay, J. (2006). Drivers of environmental behavior in manufacturing SMEs and the implications for CSR. Journal of Business Ethics, 67(3), 317-330.

Wu, C., Tang, W., \& Zhang, L. (2014). Political connections, property rights and tunneling: Empirical evidence from China's SH A-share listed companies in manufacturing. Chinese Review of Financial Studies, 3, 49-62.

Xiao, M., \& Xu, J. (2011). Corporate social responsibility information disclosure's status and improvement of China's listed private companies. The Chinese Certified Public Accountant, 1, 106-111.

Xin, J. (2008). Research of corporate social responsibility from the perspective of stakeholder theory: based on a survey of 1400 corporations in Shandong province. Journal of Shandong University (Philosophy and Social Sciences), 1, $120-126$.

Yang, T. (2009). Annual Report on China's Philanthropy Development. Social Science Documentation Publishing House Press.

Yi, F., \& Xu, E. (2014). The relationship between political connection of top managers and corporate social responsibility - an empirical study of Chinese listed companies. Research on Economics and Management, 5, 5-13.
Yu, M., \& Pan, H. (2008). The relationship between politics, institutional environments and private enterprises' access to bank loans. Management World, 8, 9-21.

Zimmerman, J. L. (1983). Taxes and firm size is. Journal of Accounting and Economics, 5(2), 119-149.

Zhang, J. (2013). Competition-commitment-compliance: motivation of Chinese enterprises' charitable donations. Management World, 9, 1180129.

Zhang, P., \& Liang, B. (2012). Political connections and fulfillment of corporate social responsibility: evidence from private listed companies in China. Accounting and Economics Research, 26(5), 14-23.

Zhou, J., Wang, W., \& Liu, X. (2008). CSR and company performance-based on listed companies in Shanghai and Shenzhen. Modern Management Science, 1, 3-6.

\section{Submit your manuscript to a SpringerOpen ${ }^{\circ}$ journal and benefit from:}

- Convenient online submission

- Rigorous peer review

- Immediate publication on acceptance

- Open access: articles freely available online

- High visibility within the field

- Retaining the copyright to your article

Submit your next manuscript at springeropen.com 